\title{
Effect of Plant Growth Retardants on Carnation (Dianthus caryophyllus L. var. Orange viana) in Prayagraj Agro-climatic Condition
}

\author{
Abin K. James*, Devi Singh and Urfi Fatmi \\ Department of Horticulture, Sam Higginbottom University of Agriculture, Technology and \\ Science (SHUATS), Prayagraj, India \\ *Corresponding author
}

A B S T R A C T

\begin{tabular}{l} 
K e y w o r d s \\
CCC (Cycocel), \\
MH (Maleic \\
Hydrazide), \\
ETHRIL \\
(Ethephon), Plant \\
Growth Regulator, \\
PGR, Plant growth \\
retardants, \\
Carnation \\
\hline Article Info \\
Accepted: \\
17 September 2020 \\
Available Online: \\
10 October 2020
\end{tabular}

\section{Introduction}

Dianthus caryophyllus L., which belongs to the family Caryophyllaceae having a diploid chromosome number, $2 \mathrm{n}=30$ is native to the Mediterranean region. Even though the popularity, the commercial growers faces certain practical difficulties, among that, the main is apical dominance. Carnation is preferred to roses and chrysanthemums by several exporting countries, on account of its excellent keeping quality, wide range of forms and colours and ability to withstand long distance transportation. Cut carnations, roses and chrysanthemums contribute close to $50 \%$ of the world cut flower trade (Kiss et al., 2001).Apical dominance is one of the serious problems for commercial carnation growers, as it does not permit the lateral buds to develop, resulting in a limited number of lateral branches and flowers (Pathania et al., 2000). Commonly in carnation, the length of the shoot is another problem. To tackle most 
of the problems which are faced by the grower's several growth retardants have been used to analyze their effect in inducing more likely characters like an increased number of healthy branches, dwarfness, reduced internodal length.

Plant growth retardants are synthetic organic chemicals which, when applied to a responsive plant, reduce the rate of stem elongation, generally without eliciting serious developmental malformations (Cathey, 1964). The category of growth retardants comes directly under plant growth regulators. Their effect on stem growth has been traced to the sub-apical region of the shoot tip, where cell division and, to a lesser extent, cell elongation are inhibited growth retardants and pot plants (Sachs and Kofranek, 1963; Wilde and Edgerton, 1969).

Certain retardants, inhibit the biosynthesis of gibberellins required to maintain sub apical meristem activity. Some growth retardants are of economic importance in agriculture and horticulture like cycoel, $\mathrm{MH}$, Ethrel since they can be employed to affect the morphology of cultivated plants in the desired way. Maleic hydrazide ( $\mathrm{MH})$ has been introduced into agriculture as a major commercial herbicide and a depressant of plant growth and in retardation of flowering and prolongation of the dormancy period. Cycocel presumably inhibits cell growth but does not reduce the number of cells. Ethephon is a systemic plant growth regulator belonging to the phosphonate family. It is readily absorbed by the plant and releases ethylene which is a natural plant hormone. Ethephon may be employed to increase branching in crops by increasing the ratio of ethylene: auxin, which diminishes apical dominance and releases axillary buds, resulting in enhanced lateral branch development.

\section{Materials and Methods}

The experiment was conducted in Naturally ventilated polyhouse at Department of Horticulture, Sam Higginbottom University of Agriculture, Technology and Science, Prayagraj. The study was laid out as Randomized Block Design with 16 different treatments which were replicated 3 times. Variety used for experiment was Orange viana. Three retardants were selected for the experiment Cycocel, Ethrel, Maleic hydrazide (500 ppm, 750 ppm, 1000 ppm, 1250 ppm, $1500 \mathrm{ppm}$.) in varying concentration.

\section{Results and Discussion}

Minimum plant height after spraying was recorded in CCC @ 1500 ppm $(57.7 \mathrm{~cm})$ followed by CCC@1250 ppm (59.00 cm) and the highest plant height was observed in plants sprayed with water that is the control $(78.53 \mathrm{~cm})$. CCC @ 1000 gave highest shoots per plant (7.6) followed by MH @ 1500ppm (7.5) and CCC @ 1500 (7.5), least value was recorded in CCC @ 500ppm (3.6). Maximum number of leaves was recorded in CCC @ 1500 ppm (135.07) followed by CCC @ 1250 (132.27) and minimum number of leaves was recorded in ETHREL @750ppm (111.33). minimum number of days taken to flower bud appearance (87.56) was recorded in control. Highest days to flower bud initiation were taken in CCC @ 1500 ppm (111.11), Followed by MH@1500 (109.16). Maximum stalks were harvested from the treatment CCC @ 1000ppm (6.6) followed by MH @ 1000 (6.5) and CCC @ 1250ppm (6.2). Least number of cut flower was obtained from ETHREL @ 1250 (4.43). CCC @ 1000 ppm gained maximum Cost Benefit Ratio (1:5.31) followed by MH @ 1000 ppm Cost Benefit Ratio (1:4.95) (Table 1). 
Table.1

\begin{tabular}{|c|c|c|c|c|c|c|c|}
\hline \multirow[b]{2}{*}{ Treatments } & \multicolumn{3}{|c|}{ Vegetative Parameters } & \multicolumn{3}{|c|}{ Floral Parameters } & \multirow{2}{*}{$\begin{array}{c}\text { Economics } \\
\text { Cost : benefit } \\
\text { ratio }\end{array}$} \\
\hline & $\begin{array}{l}\text { Plant } \\
\text { height }\end{array}$ & $\begin{array}{c}\text { Number of } \\
\text { leaves }\end{array}$ & $\begin{array}{l}\text { Number of } \\
\text { side shoots }\end{array}$ & $\begin{array}{c}\text { Bud } \\
\text { Initiation }\end{array}$ & Vase life & $\begin{array}{l}\text { Cut flower stalks } \\
\text { flowers per season }\end{array}$ & \\
\hline Control & 78.53 & 127.90 & 4.10 & 87.57 & 09.03 & 4.46 & $1: 3.53$ \\
\hline MH@500ppm & 72.66 & 119.41 & 5.07 & 94.30 & 11.17 & 5.46 & $1: 4.40$ \\
\hline MH@750ppm & 66.03 & 116.03 & 5.53 & 95.70 & 11.73 & 5.86 & $1: 4.77$ \\
\hline MH@1000ppm & 66.73 & 119.30 & 6.36 & 103.47 & 12.20 & 6.50 & $1: 4.95$ \\
\hline MH@1250ppm & 64.40 & 125.33 & 5.43 & 104.47 & 12.30 & 5.43 & $1: 4.33$ \\
\hline MH@1500ppm & 60.63 & 128.63 & 7.53 & 109.17 & 12.47 & 5.56 & $1: 4.44$ \\
\hline CCC@500ppm & 72.73 & 115.03 & 5.10 & 99.53 & 10.53 & 5.80 & $1: 4.53$ \\
\hline CCC@750ppm & 62.90 & 114.10 & 4.50 & 98.43 & 10.80 & 5.93 & $1: 4.59$ \\
\hline CCC@1000ppm & 64.30 & 122.37 & 7.60 & 106.07 & 11.83 & 6.66 & $1: 5.31$ \\
\hline CCC@1250ppm & 59.00 & 132.27 & 6.40 & 107.53 & 11.97 & 6.23 & $1: 4.87$ \\
\hline CCC@1500ppm & 57.70 & 135.07 & 7.50 & 111.10 & 12.83 & 5.36 & $1: 4.20$ \\
\hline $\begin{array}{l}\text { ETHREL@ } \\
\text { 500ppm }\end{array}$ & 71.90 & 112.23 & 5.43 & 90.03 & 08.63 & 4.53 & $1: 3.65$ \\
\hline $\begin{array}{l}\text { ETHREL } \\
@ 750 \mathrm{ppm}\end{array}$ & 68.83 & 111.33 & 4.40 & 97.10 & 08.43 & 4.50 & $1: 3.66$ \\
\hline $\begin{array}{l}\text { ETHREL } \\
@ 1000 \mathrm{ppm}\end{array}$ & 66.46 & 114.67 & 5.30 & 97.07 & 08.33 & 5.06 & $1: 4.01$ \\
\hline $\begin{array}{l}\text { ETHREL } \\
\text { @1250ppm }\end{array}$ & 64.76 & 111.47 & 5.50 & 102.97 & 07.90 & 4.43 & $1: 3.58$ \\
\hline $\begin{array}{l}\text { ETHREL } \\
@ 1500 \mathrm{ppm}\end{array}$ & 63.80 & 119.37 & 5.66 & 107.77 & 07.57 & 4.53 & $1: 3.63$ \\
\hline Mean & 66.34 & 120.28 & 5.75 & 100.77 & 10.48 & 5.40 & \\
\hline F-test & $\mathbf{S}$ & $\mathbf{S}$ & $\mathbf{S}$ & $\mathbf{S}$ & $\mathbf{S}$ & $\mathbf{S}$ & \\
\hline S. Ed. $( \pm)$ & 0.39 & 1.10 & 0.35 & 0.82 & 0.30 & 0.29 & \\
\hline CD (5\%) & 0.81 & 2.24 & 0.71 & 1.67 & 0.60 & 0.59 & \\
\hline
\end{tabular}


Reduced plant height at CCC @ 1500 ppm might be due to the interference of this chemical with auxin, may have resulted a anti-auxin reaction in plant. the action of CCC as an anti-auxin and by suppression of apical dominance which was suggested by Crafts et al., (1950). As the concentration is increased interference with endogenous hormones have resulted in overall retardation of plant, due to this reason CCC@1000 ppm resulted in maximum number of side shoots but beyond this concentration a decline in no of shoots was observed.. Youssef et al., (2013) suggested that increase in the endogenous level of cytokinin may have led to the increase in lateral shoots per plant. CCC @ $1500 \mathrm{ppm}$ resulted in delay in bud initiation may be related to the capacity of growth retardants to reduce the level of endogenous gibberellins to a permissible concentration required for flowering, Malik et al, (2017) in dahlia, Khan et al (2012) in African marigold. Maximum stalks were harvested from the treatment CCC @ 1000ppm (6.6) followed by MH@ @ 1000 (6.5) and CCC @ 1250ppm (6.2). Least number of cut flower was obtained from ETHREL @ 1250 (4.43). Flower yield was increased due to reduction of plant height by suppressing the apical dominance, which increased the main and secondary branching, thereby increasing the flower number. Similar results were observed by Maheswari and Sivasanjeevi (2019) in tube rose. Khan et al., (2012) in African marigold, Ahmad et al., (2007) in carnation. CCC @ 1000 ppm gained maximum Cost Benefit Ratio (1:5.31), increment in Cost: Benefit is due to the increasing number of flowering shoots.

In conclusion among the three growth regulators, CCC @ 1000 ppm was most effective for increasing number of shoots, highest number of flower stalks while CCC @ $1500 \mathrm{ppm}$ was effective in retarding plant height, increasing number of leaves, delaying bud initiation. And highest cost: benefit ratio was obtained from CCC@ 1000 ppm.

\section{References}

Ahmad, I., Ziaf, K., Qasim, M., and Tariq, M. (2007). Comparative evaluation of different pinching approaches on vegetative and reproductive growth of carnation (Dianthus caryophyllus). Pak. J. Agri. Sci, 44(4), 563-570.

Cathey, H.M. (1964), Physiology of growth retarding chemicals, Ann. Rev. Plant Physiol. 15, 271-302.

Crafts, A. C., Currier, H. B. and Day, B. E. (1950). Response of several crop plants and weed to maleic hydrazide. Hilgardia. 20: 57-80.

Khan, M. I., Muzamil, S., Abid, M., Aamir, H., and Mathew, B. (2012). Effect of different levels of cycocel and maleic hydrazide on growth and flowering of african marigold (Tagetes erecta 1.) cv. Pusa narangi gainda. Asian Journal of horticulture, 7(2), 294296.

Kiss, Z. O., Balogh, A., and Fodorpataki, L. (2001). Investigation of the in vitro regeneration of mericlones in the Caribe variety of carnation. International Journal of Horticultural Science, 7(3-4), 87-89.

Maheswari, T., and Sivasanjeevi, K. (2019). Response of tuberose (Polianthes tuberosa L.) cv. Single to plant growth regulators. Annals of Plant and Soil Research, 21(1), 48-50.

Malik, S. A., Rather, Z. A., Wani, M. A., Din, A., and Nazki, I. T. (2017). Effect of growth regulators on plant growth and flowering in dahlia (Dahlia variabilis) cv. Charmit. Journal of Experimental Agriculture International, 1-7.

Pathania, N.S., O.P. Sehgal and Y.C. Gupta. 2000. Pinching for flower regulation in Sim Carnation. J. Orna. Hort., 3: 114117. 
Sachs, R.M. and Kofranek, A.M (1963) Comparative cytohistological studies on inhibition and promotion of stem growth in Chrysanthemum morifolium. Am. J. Bot. 50: 772-779.

Wilde, M. H., and Edgerton, 1. J. (1969). some effects of a growth retardant on shoot meristems of apple. journal of the american society for horticultural science, 94(2), 118.

Youssef, A. S. M., and Abd El-Aal, M. M. M. (2013). Effect of paclobutrazol and cycocel on growth, flowering, chemical composition and histological features of potted Tabernaemontana coronaria Stapf plant. Journal of applied sciences research, 9(11), 5953-5963

\section{How to cite this article:}

Abin K. James, Devi Singh and Urfi Fatmi. 2020. Effect of Plant Growth Retardants on Carnation (Dianthus caryophyllus L. var. Orange viana) in Prayagraj Agro-climatic Condition. Int.J.Curr.Microbiol.App.Sci. 9(10): 2104-2108. doi: https://doi.org/10.20546/ijcmas.2020.910.256 